\title{
Communication And Community Empowerment In National Program For Community Empowerment (Pnpm) Mandiri In Serang City
}

\author{
Ipah Ema Jumiati ${ }^{1,}, \mathrm{H}$. Entang Adhy Muhtar ${ }^{2}, \mathrm{Hj} . \mathrm{R}$. Ira Irawati ${ }^{3}$ \\ ${ }^{1}$ Lecturer at the University of Sultan Ageng Tirtayasa Serang Banten, Indonesia \\ ${ }^{2}$ Lecturer at the University of Padjadjaran Bandung, Indonesia \\ ${ }^{3}$ Lecturer at the University of Padjadjaran Bandung, Indonesia
}

\begin{abstract}
Communication was one of the factors that determine the success of the implementation in National Program for Community Empowerment (PNPM) Mandiri in Serang city with target users program is poor. Therefore poverty reduction as a multi-dimensional problem can not be done only with economic empowerment for community empowerment, both individually and in a group in solving a wide range of related issues therein were an effort to improve the quality of life, independence and prosperity. PNPM Mandiri which focuses on empowering directed to involve poor communities from the planning, implementation and monitoring through the harmonization and development of systems and mechanisms and procedures of the program, providing mentoring, and funding stimulant was expected to encourage initiative and innovation communities in sustainable poverty reduction efforts. The results of research using qualitative approach stated that in implementing the policy that became one of the important reasons that bacame a source of failure in community empowerment program was less rooted communication program.
\end{abstract}

Keywords: Communication, Empowerment, Community, The PNPM Mandiri

\section{BACKGROUND}

The importance of communication not only in enclosed spaces, but also in open spaces closing in on people's lives. The communication can be seen through socialization and coordination, which is the determining factor that communities know the programs implemented by the government, including programs of poverty alleviation through community empowerment. In fact the communication process is not instant that once done then it can be easily understood by the public, but it needs to be repeated and continuous effort to let the community at least understand how to plan, implement and evaluate programs, including poverty alleviation programs in the region.

Poverty is multi-dimensional problem that can not be overcome only with economic empowerment, poverty is basically an effort to empower the poor self-sufficient, in the economy, culture and politics. A comprehensive policy is needed to improve the ability of communities to empower themselves. The problem is then that a policy agenda to be formulated not easy, especially if the policy does not involve a variety of interest groups or stakeholders as a user.

Within the framework of the implementation of public policies, the efforts of mainstreaming poverty reduction Indonesia Government has done and put poverty reduction as the top priority of national development policy.

The various policies in the RPJM 2004-2009, are expected to reduce the percentage of poor population to $8.2 \%$ in 2009 and 2015 to $7.2 \%$ (Bappenas 2005). More than that, Indonesia even participated in the signing of the Millennium Declaration in September 2003, which adopted the Millennium development goals, (Millennium Development Goals/MDGs), and the MDGs become important reference in the implementation of development in Indonesia, from the planning stages are contained in Medium-Term National Development Plan (RPJMN) to the stage of implementation.

Unsuccessful policies, sourced from the way of understanding and poverty reduction is always interpreted as a purely economic conditions. As a result of that view, poverty alleviation projects or community empowerment underlayer only as efforts on the improvement of economic conditions (increased income) and cultural change through working training projects for the poor to increase productivity.

Increasing the number of the poor, encourages the government issued various anti-poverty policies from different departments or sectors. One of these the subdistrict development program (PPK). Successful implementation of PPK, PPK I to III, which has been ongoing since 1998-2006, the Indonesian government 
decides to continue efforts to accelerate poverty reduction and unemployment in the country by using the mechanisms and PPK scheme.

This large agenda is implemented in larger scale (not only coverage location, time of implementation but also the allocation of funds), which was then known as National Program for Community Empowerment (PNPM). Through PNPM Mandiri reformulated the mechanism for poverty alleviation efforts involving elements of society, ranging from planning stages, implementation, monitoring and evaluation.

The policy of National Program for Community Empowerment (PNPM) Mandiri a very vigorous popularized by the Government gives a glimmer of hope for the poor, but when implemented between what was expected with what was realistic, it has not met the expectations of the community. From the results of observation and evaluation, indicate that activities tend to be more oriented towards the pursuit of the target achievement of physical building and ignore the aspect of community empowerment process, so the process of community empowerment as well as in the document, running only to fulfill the procedures when the project progresses. Barely less there is the role of the community after the project is completed, for example, community participation and responsibility in the maintenance of facilities.

In 2009 Number of Pre-prosperous family in Serang city amounted to 18.907, Prosperous Family I amounted to 29.095 and Prosperous Family II amounted to 45.743 with the number of poor families head amounting to 21.427 people. Even in the poorest societies provided that priority became the main recipient, it turns out that not everything is a poor category as planned, there is even the recipient has repeatedly received assistance from other poverty programs, because it is not recorded properly. Each instance has a target and the data of the different target groups (sectoral), so the program coordination between sectors and regions are weak and are not integrated. Community participation has been implemented according to existing guidelines, but the level of quality is still far from satisfactory. The size of the participation is still limited willingness of society contribute in infrastructure development, while participating in the project management process is relatively not get attention.

Accountability and transparency of management and refund PNPM assistance, also still leave the problem, funds managed difficult are justified and less touching the issue of of poverty alleviation to improve the empowerment of the poor, because it is not done thoroughly and the result does not show significant results. Based on the data obtained, the associated lack of accountability has found bottleneck in the revolving loan repayment by the community recipient of about $70 \%$. Then the allocation of resources that is less proportional, is almost $93.08 \%$ of activities directed at the construction of environmental facilities, such as making MCK (shower, washing, toilet), roads, garbage dumps, and others. As a result of economic and social areas of activity many not be implemented.

Related to the lack of transparency, can be seen from the data of recipients who do not clearly the name, address and occupation, but only lists the coupon recipients of Unconditional Cash Transfer (BLT). Even created new problems, because the implementing authorities do not have the same perception in understanding poverty reduction program. Strengthening of the institutional social formed as empowering, its role has not been adequate in the decision-making process, no more as the executor.

Thus the author assumes that one of the factors that need to be strengthened is the communication within the PNPM Mandiri through various communication media that is so important to be explored further.

\section{COMMUNICATION AND COMMUNITY EMPOWERMENT}

\subsection{Definition of Communication}

The term communication or communication in English according to Effendy (2009: 9) in his book "Ilmu Komunikasi : Teori dan Praktik" is derived from the Latin word communicatio, and sourced from the word communis that means the same. The same here means the same meaning.

Further Effendy (2009 : 9) says that, definition the communication presented on top of fundamental nature, within the meaning of the word that communications should contain minimum similarity of meaning between the two parties involved. Said to be minimal because of the communication activities are not only informative, i.e. so that other people understand and know, but also persuasive, i.e. so that others are willing to accept a doctrine or belief, perform an act or activity, and others.

In addition to understanding of communication above, in the context of public policy implementation, the author refers to the Model Edward III who declared that before outlining the important factors in the study of implementation of asking 2 principal questions: (1) what things are a prerequisite for an implementation successfully; (2) What is the main obstacle to the successful implementation of the program? Based on these two questions formulated four factors or variables that are the most important requirements for the success of the implementation process. The four factors are factors of communication, resources (resources), a disposition or tendency of the executor and the structure of the Organization and the work flow of the implementing bureaucracy. 
From these four factors communication is placed in the top position in the magnitude of the impact on the effectiveness of policy implementation. It deals with the interrelationship and interaction between actors policy makers (decision maker) with actor implementing the policy, as well as communication between the implementers of the target group. Communicating can provide the clarity of the information to be submitted.

The communication factor becomes very important in the implementation of policies, because although the resultant policies already have good quality and aim to the fulfillment of the public interest, but if the implementor does not have a clear understanding, a complete and comprehensive about the meaning and purpose of the policy, then surely they will deliver it with vague, narrow and limited. So consequently made possible the a priori attitude, even going on the rejection of the policies of the target group.

Generally Edward III discusses 3 important things in the process of communication policy namely the transmission, consistency and clarity. The first requirement for effective implementation of the policy is that those who carry out the decisions need to know what they should do, because it is very important the factors: 1. Transmission:

Transmission process in communications policy and communications policy implementation is determined by the source of the communication (human), receiver (human), media (human or apparatus or method) as well as other factors, that matter (policy) itself and barriers (communication gap) that occurs among others due to noise. Communicator serves as a policy decision (policy maker) and implementor of policies in fact are on several layers of bureaucracy. Communication barriers can be due to the Communicator, or the message recipient can also be because the messages and media used.

Viewed from the side of policy, to be implemented of course will have also obstacles especially in the delivery of the message, because it's Edward III (1980:18-26) conveys some of the factors a barrier in communication or conveying policy as follows:

1) The lack of agreement (disagreement) from the implementor in addressing the problems of policy implementation, so often running singly and deviate from the rules.

2) Levels of excessive bureaucracy, so that lines of communication become longer.

3) Use of an indirect sense, which can invite a different interpretation.

4) Unavailability of channels (channels) are adequate to convey the message of the research.

5) misperceptions about the meaning of the policy, but there is a reluctance to understand the actual meaning, so that each tries to give the sense with approximately.

\section{Clarity (Clarity).}

Information is so important in policy implementation, because although has been delivered properly to the recipient of the message, but will not necessarily be done well if the information submitted is not clear. The impact on the decision that gave birth to the different perceptions of the implementor of the information received and the likely implementation of the policy will not be effective.

\section{Consistency}

Consistency of communication for the implementation of the policy is very important, to keep the perception, confirming the direction of the implementation as well as maintaining a stance against policy, so until the achievement of the expected performance of the policy. Communication inconsistencies in policy implementation can occur as a result of the replacement officials, policy changes, the effect of strong externalities such as the results of the performance evaluation program, the values of the interests of the political, economic, social, thus affecting the level of support for policy implementation.

\subsection{Definition of Community Empowerment.}

The mainstream of public policy in poverty reduction, its end is led to the Community Empowerment (empowerment), where the poor reduction Strategies according to Dwiyanto (1995:4) is no longer only oriented on welfare (welfare oriented strategy) through delivered development sheer but more focused on efforts on empowernment or community empowerment. Such poverty alleviation models no longer leads to charity strategy, because the strategy is more oriented Assistencialism, (Freire, 1974 in Moelyarto, 1995: 24) regarding the community as assisting objects or objects of assistance in various social services and provision of social amenities. It further increase the community dependence on the government degrading human dignity, which the Government is in fact creating a new beggar.

Humanitarian issue is the core foundation of empowerment, as expressed Sumodiningrat (1999: 44) that the community empowerment is also an effort to improve the dignity and the prestige of the community who under present conditions it difficult to escape the trap of poverty and underdevelopment.

The empowerment approach to a more human-oriented enables the community to develop their own potentials. The creation of a climate that allows the creation of developing societies (enabling), the efforts of strengthening the potential of the community (empowering), and protection (Sumodiningrat, 1999: 44).

Thus it can be said that the empowerment process has a tendency that emphasizes the process of granting powers to other communities to be more empowered. 


\section{COMMUNICATION AND COMMUNITY EMPOWERMENT IN NATIONAL PROGRAM FOR COMMUNITY EMPOWERMENT (PNPM) MANDIRI IN SERANG CITY}

Good communication is needed in policy implementation, in particular communication is interwoven between the stakeholders, both in one unit executing agencies and inter-agency unit, even implementing interrelated agencies. In addition, the communication also should be well interwoven between the executive and the public.

The implementation of PNPM Mandiri program in Serang city, power support of the communication is done by the Regional Management Consultants to levels Facilitator / companion through the provision of various means of communication are created. Furthermore, the facilitator will forward to the Agency for Community Self-Reliance (BKM) and the Community Self-Help Group (KSM).

Communication largely determines the success of the objectives of the policy implementation. The effective implementation occurs if the decision makers already know what they are doing. Knowledge of what they do can be run well, so any decisions on policy and implementation rules must be transmitted or communicated) to the right people. In addition, the policy communicated to be precise, accurate, and consistent. Edwards III in his book Implementing Public Policy (1980: 17) says that:

"The first requirements for effective policy implementation is that those who are to implement a decision must know what they are supposed to do. Policy decisions and implementation orders must be transmitted to the appropriate personnel before they can be followed. Naturally, these communications need to be accurate, and they must be accurately perceived by implementors".

Communication is needed in order to the decision-makers and the implementor will be more consistent in implementing any policy implemented in the community. There are 3 indicators that can be used to measure the success of the communication variables above, namely:

\subsection{Transmission (Transmission)}

Distribution of good communication will be able to produce a good implementation too. Often what happens in the distribution of their communication presence of misunderstanding.

Related to the above transmission, the intensity of delivery information received lots submitted by the group facilitator. "Regional Management Consultant (KMW) through Faskel BKM convey information information to the Executive Board BKM, Executive Board BKM and BKM member held a meeting once a month at the BKM Secretariat".(Interview with coordinator of BKM Village of Terondol, District of Serang: Friday, May 1, 2009) From the statement above, it is known that the flow of information flows to the BKM in a hierarchical obtained through Group Facilitator (Faskel) as the length of the Territory of the Regional Management Consultants in charge of accompanying BKM.

Communication certainly requires an adequate means of communication, there are several means of communication used in the implementation of PNPM Mandiri reached via two pathways, namely advertising and public relations, which are as follows:

\section{Advertising}

(1) Public Service Ads

Public service ads will be created and screened to build attention (awareness) about the principles, values and the concept of PNPM Mandiri. To support the overall process that occurs in PNPM Mandiri, then made three themes, each theme can be delivered through three versions of the story and served through local radio, television and national newspapers. Each theme is launched in line with the conditions in the field, so it will encourage the process of understanding the community recipient as well as the strategic group that will support the success of PNPM Mandiri. At the level of villages, the facilitator can also take advantage of this advertising as a tool to explain to the public, so the community also realize that they do actually part of national activities to combat poverty independently.

(2) Radio Adlips

Radio adlips (reading a script for a distraction event) is quite effective to convey a special message to the recipient. Adlips Radio can be a channel of communication facilitators villages so faster to reach a lot of people in a specific area.The implementation of radio adlips is more on socialization consultants, KMP (Management Consultant province, KMW (Regional Management Consultants), in cooperation with the team of facilitators and cadres as giving feedback on the material in accordance with the schedule of work in each area. KMP must oversee the screen schedule and the suitability of the concept of the message delivered by the national schedule. 
Related tool of communication through radio media adlips been done by KMW Banten Province through in Serang District facilitators, as disclosed economic Field Facilitators KMW-DKI Jakarta and Banten Province, follows:

" Consultants has conducted socialization PNPM Mandiri in Serang city, namely in Harmony FM Radio Serang area located in Drangong because we subscribe there. Regarding the purse of KMW". (Interview: Serang; Wednesday, January 13, 2010)

\section{Public Relation and Mold Material}

At project PNPM Mandiri on urban, one of the responsibilities of socialization is included disseminating a variety of information that support the processes that are expected to occur in the PNPM Mandiri, such as, among others, the process of democracy, participation, transparency, and so on, which will be conducted through public relation which includes in it the following activities: 1) orientation Workshop); 2) Offers news (news pitching); 3) press conferences; 4) Press release (news distribution); 5) Media monitoring; 6) Strategic Group Gatherings; 7) Event; 8) Talk show radio (local live and pre-recorded nationally); 9) website and content management; 10) Focused Group Discussion; 11) Gathering of citizens; 12) workshop on the use of the internet; 13) The visit of journalists to the project area.

Related to the existence of the tool of communication as a factor supporting implementation of PNPM Mandiri in Serang city, one of a team of experts KMW-PNPM Mandiri Banten and Jakarta suggested:

"The tool of communication used for up till now is through the media of socialization, workshops, seminar. Besides, supported by a general Handbook, implementation guidelines, SOP-SOP (Standard Operational Raw), banner, poster, leaflet, and others. In the hands of consultants also held a community learning consultant in stages in order to increase the capacity of consultants ". (Interview:Serang; Monday, January 4, 2010)

From some of the tools of communication above, either through media advertising or public relations, in practice not everything can be understood the meaning easily by implementing the PNPM Mandiri, particularly at the level of BKM and KSM because the message is not to completely, even misunderstandings occurred because of the intensive information delivery is carried out when there will be a program only.

From the results of the interview above, it is known that intensive communication is expected to be done intensively at the time before the program started, when held up to the program was completed. In addition, the process of mentoring from a consultant also carried up to the level of KSM through a persuasive communication with media that is affordable, easy to understand, and received the community so the information presented can be understood to mean the exact meaning by the people,not just the authorities implementing agency only, as expressed by Edwards III (1980) in Saefullah (2007:50):

"Understanding the implementation of policies not only be possessed by the authorities implementing agencies but also by the public or targeted community policies. The next step in the implementation of the policy is to conduct socialization in order for the policy is known, understood, and accepted by all parties concerned. This activity should be done through persuasion communication with the selection of media that is affordable and easy to understand communicant".

So we can conclude, if it happens the same purport between communicators, namely apparatus PNPM Mandiri with the communicant, is that the recipient of the program, then the communication is said to successfully achieve the desired goal, so avoid misunderstandings so that the information submitted can be received well until the smallest group poor people who receive program benefits. Besides the availability of tools of communication that support and adequate also play an important role in supporting the successful implementation of the policy.

\subsection{The Clarity (Clarity)}

The second factor is the clarity Edwards stated. Known based on the results of observation and interviews are often instructions forwarded to implementers vague and did not specify when and how a program is implemented. Obscurity communication message that are submitted regarding the implementation of policy leads to an incorrect interpretation may even be contrary to the meaning of the original message. However, the vagueness of communication messages do not necessarily preclude the implementation of policies, in particular the level of the policy implementers need flexibility in implementing the policy.

Edwards in Winarno (2007 : 177) identifies six factors that encourage the occurrence of communication policy vagueness. These factors are the complexity of the policy, the desire not to disturb the community groups, the lack of consensus on policy objectives, problems in starting a new policy, the avoidance of liability policies, and the nature of the court policy formation.

Forms of community participation program recipients in connection with the PNPM Mandiri in Serang District are labor, material donations / goods, money, consumption (food), non-governmental, mutual cooperation, involvement in the deliberations and involved from planning, implementation to evaluation of the program. 
Coordinator of the BKM Village of Terondol, District of Serang argued:

"This form of public participation is in the form of mutual cooperation to build roads and other public facilities such as MCK, road paving block, a garbage, water-channel. (drainage), construction of water supply. There are also people who donate building materials, such as cement and sand, although only slightly. The problem is middle economic people on the complex environment of indifference, did not want to intervene, the donation if requested ". (Interview: Serang; Friday, May 1, 2009)

From the results of the interview above known that in the complex environment in community engagement of the upper middle economic strata will be there when requested, even tend not to care about the PNPM Mandiri program as poverty reduction efforts. So it can be said to lack of solidarity.

Communication barriers with the implementor of PNPM Mandiri in the implementation of PNPM Mandiri in Serang are some people which have a mental attitude that assumes that the PNPM same as the Social Safety Net program earlier times, as proposed by the Expert Team KMW-PNPM Mandiri Banten and DKI Jakarta, following :

" The barriers that occurred are still some people have the mental attitude which assumes that the PNPM same as the Social Safety Net program earlier times. Therefore, the choice for the community, whether it can be committed or not. Various poverty programs prior partial, sectoral and in fact often face a less favourable condition. (Interview: Serang; Monday, January 4, 2010).

Further that the condition of social capital as well as public behavior that weaken and fade the one is caused by the decisions, policies and actions of the poverty program managers and community leaders that tend to be unjust, not transparent and not the responsibility of worship (not pro-poor and good governance oriented). It gives rise to suspicion, stereotypes and skepticism in the community.

Other communication barriers are the difficulty of gathering members of BKM and the lack of citizens' initiatives to implement the program.

Based on the result of the interview above, according to the author's analysis that the barriers of communication that arises is that the public is sometimes difficult to get involved in development programs, although it is to increase the degree of their life. Such as posed Weber that prosperity/welfare must be achieved with hard work and frugal living. This kind of approach in the cultural perspective that viewed poverty characterized by properties such as apathy, resignation to fate, wasteful and dependent (Kamanto, 2000:7).

Communication becomes clear while the information received from the leadership not convoluted, as expressed by one of the informants from the expert team KMW-PNPM Mandiri DKI Jakarta and Banten Province:

"Information from the leadership is quite clear and the first to be disseminated in order equation understanding and perception so there is no distortion at the time of implementation of the program". (Interview: Serang; Monday, January 4, 2010).

Meanwhile, Coordinator of the Regional poverty reduction Coordination Team (TKPKD) of the PNPM Mandiri Serang, said:

"The communication channels more quickly to consultants rather than to the local government. Correspondence to the consultant. Communication between TKPKP with TKPKD used to be weak because of the rare unscheduled (schedule is not clear), for the TKPKP tried to establish more intensive coordination with the district level. During this coordination meetings were held quarterly between local governments, Consultant with Stakeholders in the Villages and districts. For example: at the end of year the activities implementation plan of budget created a schedule, better contained in one document for easy coordination. Progress reports every month there". (Interview: Serang; Thursday, January 28, 2010)

From the results of the interview above note that information received from the leadership is quite clear, because the first was held socialization, quarterly coordination meeting between the Regional Government, Consultant with the PNPM Mandiri in Village and Subdistrict levels. Related information received from village chief, PJOK (responsible for Operational Activities) as well as consultants, Coordinator BKM Village Terondol sub-district Serang, said:

"During this time BKM coordinating with village, in this case the Village Chief, Mr. Fahruroji and also to the District through PJOK, Mrs. Yeti for signing the proposal activities. Lots of technical information we may be through Group Facilitator appointed Regional Management Consultants (KMW). Instead of beating around the bush, but there is hierarchical of KMW, continue to Faskel then new information to the BKM ". (Interview: Serang; Friday, May 1, 2009)

Furthermore, the facilitator economics said:

"PNPM is always changing regulations, changes in policy. It may be said quickly. With the accelerating pace of these changes there are times when we are accepting the rules were not ready. Not ready to accept this change, for example like this: on the issue of the format of the utilization of BLM yesterday that we conveied to BKM like this, it turned out that there is a new change. Means BKM had to extra work, also issued extra funds. We never inhibit, delay information". (Interview: Serang; Wednesday, January 13, 2010) 
From the results of interviews with informants in the above, it is known that the information received by the people running the hierarchical top-down (top down) so BKM is waiting for and receiving any established procedures, including changes common reporting format.

\subsection{Consistency (Consistency)}

The third factor affecting the communications policy is consistency. If the implementation of the policy would like to progress effectively, then orders the implementation should be consistent and clear.

According to Edwards III in Winarno (2007 : 178) to investigate the relationship of communication and implementation, it can take a generalization, namely that the closer the decisions and commands execution passed on to those who have to implement it, the higher the probability of policy decisions and the execution of commands executed. In situations like this, deviations of the transmission is the primary cause of failure inplementation.

"In connection with the consistency, regarding the implementation of the policy in Serang city, One of Bappeda officials Serang District argued: "In terms of program policies, of course, based on the rules and procedures that have been determined" (Interview: Serang; Friday, January 29, 2010). Meanwhile, Team Leader KMWPNPM Mandiri Banten and DKI argued: "Policies sometimes changed, this is certainly on the basis of the deliberations of the policy makers themselves solely for repair / better" (Interview: Serang; Monday , January 4, 2010).

Based on the results of the interview above, it is known that the policy has not been consistently implemented during this time because sometimes it can still change on the basis of certain considerations, so the timing of the activities already set to be slower than the target should be.

In the implementation of the PNPM Mandiri in Serang, consistency can be seen from whether the technical guide (juknis) and operational guidelines (juklak) are interpreted differently by the parts that perform duties and whether the operational guidelines and more the technical guide entrusted to the leadership to interpret it.

Facilitator Economics argued:

"Ever happened operational and technical guidelines are interpreted differently by the program managers at BKM level, this becomes the duty of Faskel. In every opportunity we have to socialize the concept of PNPM not listlessly, should remain guarded his ring that way. Many guidelines, but the outline should know. Regarding the interpretation of technical and operational guidelines, faskel is believed to explain the technical and operational guidelines ". (Interview: Serang; Wednesday, 13 January 2010).

Taktakan:

A similar response was also expressed by community leaders in the village of Sepang district of

"Guidelines and Technical Guidelines is sometimes interpreted differently due to the complicated and not everyone could instantly understand it. So it should be made more simple and easily understood by the layman. Operational guidelines and technical guidelines is more entrusted to Faskel. Faskel to BKM and UPK. UPK to members of the BKM and KSM ". (Interview: Serang; Thursday, December 17, 2009)

In contrast to the responses of informants before, One Expert Consultant Team PNPM Mandiri province of Banten and DKI argued:

"Technical Guidelines and Guidelines was not interpreted differently, sometimes not consistent in its implementation. The interpretation of the technical guidelines and operational guidelines not only relying on the leadership, but performed the analysis/examination by all actors in order to avoid incorrect or different interpretation from the whole substance ". (Interview: Serang; Monday, January 4, 2010)

From the above explanation, it can be concluded that the clarity of communication is the one defined by the factor of consistency. This situation will encourage the possibility of commands inconsistent implementation.

\subsection{Conclusions}

\section{CONCLUSIONS AND SUGGESTIONS}

Communication in PNPM Mandiri in Serang city was still found barriers of communication with implementing the PNPM Mandiri. The barrier occurred due to the implementation of the socialization activities aimed to provide an understanding of the whole regarding the PNPM Mandiri was not done in stages and the intensity is still low. Consequently it caused depth distortion so that information about PNPM Mandiri received poor who recepient the program is not intact. Further it caused difference of perception between policy makers with policy implementers.

\section{2 suggestions}

In connection with the above conclusion, the need for emphasis that information dissemination in the PNPM Mandiri plays a very important role, especially for relevant stakeholders. Therefore, to reduce the distortion of information received by the community, then the implementation of socialization should be done at the smallest unit in society is the level of the Neighborhood (RT) with participants of the at the lowest tier and 
carried out by people who really understand the substance of the program in order to reduce errors in conveying information.

\section{REFERENCE}

[1] Dwiyanto, Agus. Reformasi Birokrasi Publik di Indonesia. 1995. Yogyakarta : Gadjah Mada University Press.

[2] Edward, G. C. III. 1980. Implementing Public Policy. Washington DC : Congressional Quarterly Press.

[3] Effendy, Onong Uchyana. 2009. Ilmu Komunikasi : Teori dan Praktek. Bandung : Rosdakarya.

[4] Kamanto, Sunarto. 2000. Pengantar Sosiologi. Jakata : Fakultas Ekonomi Universitas Indonesia.

[5] Moeljarto. 1995. Politik Pembangunan, Sebuah Analisis Konsep, arah dan Strategi. Yogyakarta: Tiara Wacana Yogya.

[6] Saefullah, Djadja. 2007, Pemikiran Kontemporer Administrasi Publik (Perspektif Manajemen Sumberdaya Manusia Dalam Era Desentralisasi. Jakarta :LP3AN.

[7] Sumodiningrat, Gunawan. 1999. Pemberdayaan Masyarakat dan Jaring Pengaman Sosial. Jakarta : Gramedia.

[8] Winarno Budi. 2002. Teori dan Proses Kebijakan Publik. Jakarta : Media Pressindo. 